\title{
ASSESSMENT OF YEAST BIOFILTER IN THE TREATMENT OF DOMESTIC WASTEWATER
}

\author{
Ja'afaru, M. I.*, Bristone, J. P. and Salihu, A.A. \\ Department of Microbiology, Modibbo Adama University of Technology, P.M. B. 2076, Yola. Nigeria \\ * Corresponding author: mijaafaru@mautech.edu.ng
}

\begin{abstract}
Wastewater samples were collected from three different points in Jimeta (Nigeria). The Physicochemical, as well as microbiological analysis of the wastewater was done before and after biofiltration process. The result revealed after the biofiltration process, the $\mathrm{pH}$ was slightly reduced and was around neutral ; biochemical oxygen demand (BOD), dissolved oxygen (DO), chemical oxygen demand (COD), and the nitrate content of the wastewater were drastically reduced; elements such as magnesium (Mg), sodium( $\mathrm{Na})$, potassium( $\mathrm{K}$ ) and phosphorus(K), chloride $(\mathrm{Cl})$, carbonate and bicarbonate values were also reduced. Similarly, there was a decrease in the types and number or count of microorganisms' after the biofiltration process. The bacteria Staphylococcus aureus, Escherichia coli, Proteus mirabilis, Serratia spp, Pseudomanas spp, Shigella spp, Salmonella spp, Bacillus cereus and the fungi Aspergillus niger, Aspergillus fumigatus, Penicillum spp, Aspergillus flavus were completely eliminated after the biofiltration process. This shows the health and environmental implications associated with discharging untreated domestic Wastewater into the environment, which indeed therefore there is a need to ensure adequate treatment facilities for domestic wastewater.

Keywords:
\end{abstract}

\section{INTRODUCTION}

Water pollution is a major problem in the global context. It has been suggested that it is the leading worldwide cause of deaths and diseases and that it accounts for the deaths of more than 14,000 people daily (WHO/UNICEF, 2012). Wastewater is defined as the used water supply of a community and it consist of domestic wastewater or sewage, including human excrement and wash waters that is drained into sewage system, industrial waterborne wastes such as oils, grease, animal and vegetable matter discharged by factories and ground, surface and atmospheric waters that enters the sewage system (Tortoraet al., 2010).

Domestic wastewater mostly contains waste from home, kitchen and bathroom and consists of approximately $99.7 \%$ of water, 0.02 to $0.03 \%$ suspended solids, and other soluble organic and inorganic substances (Aneja et al., 2009). Domestic wastewater may serve as a source of pollution to the receiving water body or river, and it may in turn pose danger to the people that reside and uses the rivers for domestic and irrigation purposes (WHO/UNICEF, 2012).

In many developing countries, the bulk of domestic and industrial wastewater is discharged without any treatment or after primary treatment only. In fact, wastewater treatment receives the least attention, partly because enforcement of environmental standards is poor. In the year 2000 , the United Nations established that 2.64 billion people had inadequate access to sanitation, but in Africa and Asia approximately half of the population had no access to whatsoever sanitation. The traditional methods for wastewater purification are often laborious and expensive, considering the volume of wastewater released into the environment through various processes (Asamudoet al., 2005).

A biological filter technology is used to control water pollution by applying the use of microorganisms as agents to treat contaminated water. A great application of biofiltration is in the removal of odours and toxic gases emitted from wastewater facilities, especially hydrogen sulphite $\left(\mathrm{H}_{2} \mathrm{~S}\right)$. Biofiltration is distinguished from other biological wastewater treatment by the fact that there is a separation between the microorganism and the treated water. In biofiltration, the microbial biomass is static - immobilized to the bedding material, while the treated fluid is mobile, it flows through the filter (Basu et al., 2016). 
This paper is aimed at assessing the microbial load and physico- chemical qualities of domestic wastewater treated by biological filters in Yola, Nigeria.

\section{MATERIALS AND METHODS \\ Collection of Samples}

Domestic wastewater was collected from drainage channels in Jimeta in sterile two (2) litre capacity sample bottles and transported in an ice box to the laboratory. The wastewater was collected from three different points; point A (PA) channel along Lower luggere, point $B(P B)$ a channel along Hayin-gada and point $C$ (PC), a channel in Demsawo, all located in Jimeta metropolis. Three samples were collected at each point.

The yeast consortium consisting of six species isolated from nono(locally fermented milk)and kunun-zaki (a locally fermented beverage) were grown in $50 \mathrm{ml}$ capacity flasks containing $10 \mathrm{ml}$ of peptone water and incubated at ambient temperature for $24 \mathrm{hrs}$. After the incubation period, the cultures were centrifuged at $3000 \mathrm{rpm}$ for 5 minutes using centrifuge to obtain biomass for use as biofilter (Rabah et al., 2011).

Microbiological Analysis of Domestic Wastewater Domestic wastewater was analyzed according to the method of Adesemoye et al., (2006). Serially diluted wastewater sample was inoculated in triplicate plates of nutrient agar (NA), Mac Conkey agar (MCA) and Saboraud dextrose agar (SDA) using the surface plating method for the enumeration of total aerobic bacteria, coliforms, and fungi respectively. The NA and MCA plates were incubated at $37^{\circ} \mathrm{C}$ for 24 hours, while SDA was incubated at ambient temperature for 24-72 hrs. After incubation period, colonies which develop on the plates were counted, recorded and calculated as colony forming unit per milliliter (CFU/ml) of sample. Colonies that appeared were further sub cultured on their respective media to obtain pure cultures. The pure cultures were characterized using microscopic and biochemical methods.

Physico-chemical Qualities of Domestic Wastewater

The Physico-chemical qualities of the domestic waste water were determined using the methods of Ezeronye and Okerentugba (1999) and that of APHA, (1998). The parameters determined were $\mathrm{pH} \quad$ (Jenway, U.K 3015), electrical conductivity(Conductivity meter, Jenway, U.K 3505), dissolved oxygen (DO), biochemical oxygen demand (B.O.D) and chemical oxygen demand (C.O.D). Chloride, carbonate, bicarbonate and calcium (EDTA titration)were determined using titration method. Sodium, potassium, phosphorus, magnesium were determined using flame photometer (400 Corning Ltd, Halstead Essex, U.K). Nitratewas determined by thephenol disulphonic acid method.
Design of Biofilter and Biofiltration of Wastewater

A locally-made biofilter was made of Perspex glass measuring $16 \mathrm{~cm}$ in length, width of $10 \mathrm{~cm}$ and a depth of $10 \mathrm{~cm}$. The filter had upper and lower compartments separated by perforated partition made of the same Perspex glass. It contains a tap for collection of filtered wastewater. Potato peels was ground to smaller particles, sterilized, wetted and placed on the perforated partitions.

The yeast biomass $\left(1 \mathrm{ml}\right.$ containing $10^{5}$ cells $\left./ \mathrm{ml}\right)$ was then inoculated on the peels and left for one week at ambient temperature to allow cells grow. The domestic waste water was carefully introduced into the filter bed and left to be filtered slowly for a minimum period of 14 days. The filtered wastewater was collected from the lower chamber

\section{RESULTS AND DISCUSSION}

The wastewater collected from PA (point A along lower luggere) had the highest bacterial count of $7.3 \times 10^{6} \mathrm{cfu} / \mathrm{ml}$ before biofiltration, while the lowest was recorded from PB (point $B$ along Haying-gada) with $3.4 \times 10^{6} \mathrm{cfu} / \mathrm{ml}$. The highest Coliform count before biofiltration was recorded at point $A$ with $4.6 \times 10^{6} \mathrm{cfu} / \mathrm{ml}$ which may be due to the human population and activities going on around the area. However, after passing the wastewater through the yeast biofilter, there was a reduction in the bacterial, fungal, and coliform counts at all the three points (Table 1). During the biofiltration process the $\mathrm{pH}$ of the wastewater was reduced, the highest reduction was recorded at point $\mathrm{A}$ ( $\mathrm{pH} 7.9$ to 6.05 ). This may be attributed to microbial activities that result in the accumulation of waste products, thus making the environment unsuitable for bacterial growth. Ismite and Atuanya (2006) and Rabah et al. (2011) also reported considerable reduction in the total counts of microorganisms from textile effluent and abattoir wastewater as the $\mathrm{pH}$ of the effluent decreased after biofiltration.

In terms of bacterial, fungal and coliform counts, statistical analysis (ANOVA) indicated a significant difference between the count at point $A, B$ and that of $C(p \leq 0.05)$. The bacteria isolated from the domestic wastewater before the biofiltration were identified as Staphylococcus aureus, Micrococcus spp, Alkaligenes spp, Escherichia coli, Proteus mirabilis, Serratia spp, Pseudomonas spp, Salmonella spp, Bacillus cereus and Bacillus polymyxa. After the biofiltration only Micrococcus sppand Bacillus polymyxa were identified in all the three points (Table 2). Fungal isolates identified before biofiltration are Aspergillus niger, Aspergillus fumigatus, Penicillium echinulatum, Aspergillus flavus, Penicillium spp, Mucor spp and Absidia corymbifera. Mucor spp., and Aspergillus niger were the organisms isolated after biofiltration 
The physico-chemical qualities of the domestic wastewater were determined prior to and after biofiltration process from the three sampling points (PA, PB and $\mathrm{PC}$ ), and are presented in Table 3. It was observed that there was a considerable reduction in $\mathrm{pH}$, nitrate $\left(\mathrm{NO}_{3}\right)$, DO, BOD, and COD after the biofiltration of the wastewater collected from the three sampling points. It was also observed that the concentrations of other compounds in the wastewater varied with the sampling points probably due to contamination from human activities such as dumping of refuse in the wastewater channels. The $\mathrm{pH}$ of the wastewater in all the three points where near neutral and this may play a part in determining both the qualitative and quantitative abundance of the microorganisms in the wastewater (Adesemoye et al., 2006). As more hydrogen ions become available, the $\mathrm{pH}$ is lowered and this may affect the pattern of microbial population (Rabah et al., 2011).Ismite and Atuanya (2006) stated that mineralization of effluents by fungi was usually accompanied by a decrease in the $\mathrm{pH}$ of the effluent. The chloride level was also high and reduced from $33.6 \mathrm{mg} / \mathrm{l}$ to $3.9 \mathrm{mg} / \mathrm{l}$ on average after the biofiltration and its presence in the wastewater could be attributed to sources of pollution which might result from introduction of mineral salts into the wastewater (Adeyemo et al., 2002). There was significant reduction of nitrate in all the sampling sites and this could be as a result of biological stabilization in the effluents. The highest reduction of nitrate was achieved in the wastewater collected from PA where the nitrate was reduced from $28.01 \mathrm{mg} / \mathrm{l}$ to $7.05 \mathrm{mg} / \mathrm{l}$. In the work of Ogugbue and Oranusi (2006) where immobilized cells of Alkaligenes and Bacillus species were used to denitrify and degrade azo dyes in simulated dye wastewater, it was found that the concentration of nitrate decreased from initial value of $0.30 \mathrm{~g} / \mathrm{l}$ to $0.067 \mathrm{~g} / \mathrm{l}$. In the work of Rabah et al. (2011) yeast consortium was used in biofiltration of abattoir wastewater, it was reported that the nitrate value decreased from $16 \mathrm{mg} / \mathrm{l}$ to $0.14 \mathrm{mg} / \mathrm{l}$. Also, Ismite and Atuanya (2006) reported a nitrate content range of $90 \mathrm{mg} / \mathrm{l}-100 \mathrm{mg} / \mathrm{l}$ in raw textile effluent and after the bioremediation of the effluent the nitrate content was reduced to a range of 17.5 $\mathrm{mg} / \mathrm{l}-70.6 \mathrm{mg} / \mathrm{l}$. There was also a decrease in the biochemical oxygen demand of the wastewater after the biofiltration process. The highest reduction occurred in wastewater collected from PA where the BOD values decreased from $39.0 \mathrm{mg} / \mathrm{l}$ before biofiltration to2.0 $\mathrm{mg} / \mathrm{l}$ after biofiltration. This may be attributed to the use of yeast species which degrade the pollutant as well as the potato peels that served as biofilter.

According to Ezeronye and Okerentugba (1999) the combination of yeast and cassava peels acting as carbonaceous substrate for microbial nutrition greatly enhanced biochemical oxygen demand reduction by increasing the Carbon/Nitrogen ratio of the effluent. The investigators reported a BOD reduction from an initial concentration range of $1200 \mathrm{mg} / \mathrm{l}-1440$ $\mathrm{mg} / \mathrm{l}$ to $404 \mathrm{mg} / \mathrm{l}-135 \mathrm{mg} / \mathrm{l}$

There was a significant decrease in chemical oxygen demand (COD) of the wastewater collected from the three points; the highest reduction was recorded in the wastewater collected from PA where the COD decreased from $40.09 \mathrm{mg} / \mathrm{l}$ to $10.3 \mathrm{mg} / \mathrm{l}$. This revealed that there was successful oxidation of the organic and inorganic matter in the wastewater, signifying a reduction in the pollution load of the wastewater. The dissolved oxygen DO was also drastically reduced with the highest reduction at point $A$ from $9.17 \mathrm{mg} / \mathrm{l}$ to 1.09 $\mathrm{mg} / \mathrm{l}$. This corroborates the work of Ismite and Atuanya (2006) who reported a reduction of COD from $89 \%$ to $39 \%$ of effluent. Similarly, Melamene et al. (2007) reported an initial COD reduction of $53.3 \%$ and a total COD removal of $99.5 \%$ from wine distillery wastewater. In a similar research, Xu et al. (2005) reported high efficiency of a self-made biofilter in reducing COD of wastewater from $60 \mathrm{mg} / \mathrm{l}$ to less than $0.5 \mathrm{mg} / \mathrm{l}$.

\section{CONCLUSION}

The domestic wastewater analyzed had a considerable count and species of various fungi and bacteria, which indicates high level of contamination of the domestic wastewater Thus the adequate treatment to ensure proper decontamination is required. It also had some physicochemical properties in amounts that indicate that the wastewater was highly polluted. However, after passing the wastewater through the yeast biofilter, both microbial counts and the physicochemical qualities were reduced. Therefore, the use of yeast biofilter in the treatment of domestic wastewater is an alternative wastewater treatment strategy and hence can be improved upon for domestic use. 
Special Conference Edition, November, 2017

Table 1: Total viable counts of bacteria and fungi in domestic waste water before and after biofiltration in Jimeta

\begin{tabular}{|c|c|c|c|c|c|c|}
\hline \multicolumn{3}{|c|}{$\begin{array}{l}\text { Point of Bacteria }\left(\times 10^{6} \mathrm{cfu} / \mathrm{ml}\right) \\
\text { collection of waste water }\end{array}$} & \multicolumn{2}{|c|}{ Fungi $\left(\times 10^{4} \mathrm{cfu} / \mathrm{ml}\right)$} & \multirow{2}{*}{\multicolumn{2}{|c|}{ Coliforms $\left(\times 10^{6} \mathrm{cfu} / \mathrm{ml}\right)$}} \\
\hline Before After & Before & After & Before & After & & \\
\hline $\mathrm{PA}$ & 7.3 & 2.0 & 6.7 & 2.7 & 4.6 & 0.7 \\
\hline PB & 3.4 & 1.0 & 3.0 & 0.0 & 3.0 & 1.8 \\
\hline PC & 4.6 & 1.3 & 3.6 & 1.6 & 3.0 & 1.0 \\
\hline Mean & 5.1 & 1.55 & 4.34 & 1.43 & 3.53 & 1.5 \\
\hline
\end{tabular}

${ }^{*}$ Counts represent mean of triplicate samples; $\mathrm{cfu} / \mathrm{ml}$; colony forming unit permillitre.

PA: Point A, PB: Point B, PC: Point C

Table 2: Occurrence of Bacteria and Fungi before and after biofiltration

\begin{tabular}{llll}
\hline Bacteria & Before & After & Fungi \\
\hline Staphylococcus aureus & & - & Aspergillus niger \\
Micrococcus spp & + & + & Aspergillus fumigatus \\
Alkaligenes spp & + & - & Penicillium echinulatum \\
Escherichia coli & + & - & Aspergillus flavus \\
Proteus mirabilis & + & - & Penicillium spp \\
Serratia spp & + & - & Mucor spp \\
Pseudomonas spp & + & - & Absidia corymbifera \\
Salmonella spp & + & - & \\
Bacillus cereus & + & - & + \\
Bacillus polymyxa & + & - & + \\
\end{tabular}

+: present, -: absent 
Special Conference Edition, November, 2017

Table 3: Physico-chemical qualities of domestic wastewater before and after Biofiltration process.

\begin{tabular}{|c|c|c|c|}
\hline \multirow[t]{2}{*}{ Parameter } & PA & PB & PC \\
\hline & $\begin{array}{l}\text { Before } \\
\text { After }\end{array}$ & $\begin{array}{l}\text { Before } \\
\text { After }\end{array}$ & $\begin{array}{l}\text { Before } \\
\text { After }\end{array}$ \\
\hline $\mathrm{pH}$ & $\begin{array}{l}7.90 \\
6.05\end{array}$ & 6.805 .99 & $\begin{array}{l}7.0 \\
6.04\end{array}$ \\
\hline Electrical conductivity $(\mu \mathrm{S} / \mathrm{cm})$ & $\begin{array}{l}460.54 \\
91.9\end{array}$ & $\begin{array}{l}532 \\
58.0\end{array}$ & $\begin{array}{l}430.2 \\
48.71\end{array}$ \\
\hline $\mathrm{DO} \mathrm{mg} / \mathrm{l}$ & $\begin{array}{l}9.17 \\
1.09\end{array}$ & $\begin{array}{l}5.10 \\
2.01\end{array}$ & $\begin{array}{l}10.2 \\
4.02\end{array}$ \\
\hline $\mathrm{BOD} \mathrm{mg} / \mathrm{l}$ & $\begin{array}{l}39.0 \\
2.00\end{array}$ & $\begin{array}{l}31.2 \\
4.20\end{array}$ & $\begin{array}{l}39.9 \\
10.1\end{array}$ \\
\hline COD mg/l & $\begin{array}{l}40.09 \\
10.3\end{array}$ & $\begin{array}{l}32.30 \\
5.00\end{array}$ & $\begin{array}{l}30.09 \\
11.1\end{array}$ \\
\hline Chlorides mg/l & $\begin{array}{l}31.00 \\
4.12\end{array}$ & $\begin{array}{l}30.40 \\
3.00\end{array}$ & $\begin{array}{l}39.40 \\
3.05\end{array}$ \\
\hline Magnesium mg/l & $\begin{array}{l}21.05 \\
1.8\end{array}$ & $\begin{array}{l}27.83 \\
6.24\end{array}$ & $\begin{array}{l}21.20 \\
8.20\end{array}$ \\
\hline Sodium mg/l & $\begin{array}{l}13.0 \\
4.10\end{array}$ & $\begin{array}{l}12.11 \\
5.82\end{array}$ & $\begin{array}{l}14.10 \\
6.00\end{array}$ \\
\hline Nitrate $\mathrm{mg} / \mathrm{l}$ & $\begin{array}{l}28.01 \\
7.05\end{array}$ & $\begin{array}{l}24.62 \\
10.32\end{array}$ & $\begin{array}{l}24.30 \\
9.40\end{array}$ \\
\hline Phosphorus mg/l & $\begin{array}{l}10.18 \\
0.07\end{array}$ & $\begin{array}{l}11.61 \\
4.11\end{array}$ & $\begin{array}{l}10.60 \\
4.10\end{array}$ \\
\hline Carbonate mg/l & $\begin{array}{l}0.20 \\
0.00\end{array}$ & $\begin{array}{l}0.31 \\
0.02\end{array}$ & $\begin{array}{l}0.01 \\
0.00\end{array}$ \\
\hline Bicarbonates mg/l & $\begin{array}{l}161 \\
48.05\end{array}$ & $\begin{array}{l}172 \\
49.9\end{array}$ & $\begin{array}{l}159.50 \\
42.64\end{array}$ \\
\hline Potassium mg/l & $\begin{array}{l}38.1 \\
15.10\end{array}$ & $\begin{array}{l}30.27 \\
8.10\end{array}$ & $\begin{array}{l}28.30 \\
6.40\end{array}$ \\
\hline
\end{tabular}

PA, PB, PC: Points of collection of wastewater. mg/l: milligramme per litre. DO: dissolved oxygen, BOD: biochemical oxygen demand, COD: chemical oxygen demand, $\mu \mathrm{S} / \mathrm{cm}$ : micro siemens per centimeter. 


\section{REFERENCES}

Adebayo, A.A. and Zemba, A.A. (2003) Analysis of Microclimate Variations in Jimeta-Yola. Global Journal of Social Sciences. 2 (1):79-88.

Adesemoye, A. O., Opere, B. O. and Makinde, S. C. $O$ (2006). Microbial content of abattoir wastewater and its contaminated soil in Lagos, Nigeria. African Journal of Biotechnology 5(20): 1963-1968.

Adeyemo, O. K., Ayodeji, I. O., Aiki-Raji, C.O (2002). The water quality and sanitary conditions in a major abattoir (Bodija) in Ibadan, Nigeria. African. Journal. Biomedical. Research. 5: 51-55

American Public Health Association (APHA) (1998). Standard Methods for the Examination of Water and Wastewater, 20th Edition, Washington DC.

Aneja, K. R., Praney, J. and Aneja, R. (2009) A Textbook of Basic and Applied Microbiology. New Age International. Publishing, New Delhi, Pgs: 413- 415.

Asamudo, N. U., Daba, A. S. and Ezeronye, O.U. (2005). Bioremediation of Textile Dye Effluents using Phanerochaete Chrysosporium. African Journal of Biotechnology; 4(13): 1548-1553

Basu, O. D., Dhawan, S. and Black, K. (2016). Application of biofiltration in drinking water treatment - a review. Journal of Chemical Technology and Biotechnology 91(3):585- 595

Ezeronye, O. U. and Okerentugba, P. O. (1999). Performance and efficiency of a yeast biofilter for the treatment of a Nigerian Fertilizer plant effluent. World Journal of Microbiology and Biotechnology 15: 515-516.

Ismite, J.O. and Atuanya, E. A. (2006). Physicochemical and microbiological characteristics of textile mill effluents . Nigerian Journal of Microbiology 20 (2): 1047-1056.
Melamene, X.,Tandlich, R and Burgess, J. (2007). Anaerobic digestion of fungally pretreated wine distillery wastewater. African Journal of Biotechnology. 6(17):1990-1993

Ogugbue, C. J., and Oranusi, N. A. (2006). Denitrification and Biodegradation of Azo Dye (Orange ii and Orange G) In Simulated Dye wastewater by monoculture consortium immobilized cells of bacteria. Nigerian Journal of Microbiology 20 (2):1078 -1087

Rabah, B. A., Ijah, U. J. J., Ibrahim, L. M. and Manga, B .S. (2011) Assessment of the efficiency of a yeast biofilter in the treatment of abattoir wastewater. African Journal of Biotechnology 10 (46): 9347-9351

Tortora, G., Funke, B. Case, C. (2010). Microbiology. An Introduction. San Francisco Benjamin Cummings. Pp: 1-5.

Topare, S., Niraj .S. J and Mosleh M.M (2011) Wastewater treatment. Science Reviews and Chemical Communications: 1 (1)1824.

Xu, Y-b., Xiao, H-h.and Sun, S-y. (2005) Study on anaerobic treatment of wastewater containing hexavalent chromium. Journal of Zhejiang University of Science. 6(6):574-579

WHO/UNICEF (2012), Progress on sanitation and drinking-water: 2012 update. Geneva: World Health Organization Press. Accessed at http: / /www.wssinfo.org/definitionsmethods/watsan-categories/.

World Health Organisation, WHO (1996). Guidelines for Drinking Water Quality. Vol 2 .GENEVA 